\title{
국제개발협력 선진화 방안
}

\author{
이련주 국무총리실 개발협력정책관
}

목차
I. 들어가며
II. 국제사회의 논의 동향
III. 우리나라 개발협력의 현주소(2000년대)
IV. 국제개발협력 추진방향
V. 국제개발협력 3대 선진화 전략
VI. 국제개발협력의 기반 확대
VII. 결 론

\section{I. 들어가며}

국제개발협력은 국가별로 역사적 배경, 국정방향, 국민정서 등에 따라 시각과 철학이 다르다. 국 제개발협력을 외교안보의 중심축으로 보는 나라, 경제적 이익과 연계시키는 나라, 순수하게 인도 적 차원에서 지원하는 나라, 구식민지 국가와의 돈독한 관계를 중시하는 나라 등 각양각색이다. 우리나라의 경우 국제개발협력을 어떤 방향으로 추진할 것인가를 결정하는 데 타국의 사례도 참고 가 되겠지만 우리나라의 자체적인 특성이 가장 중요하다고 하껬다.

우리나라는 $\mathrm{ODA}$ 에 관한 한 수원국이자 공여국이었다. 우리나라는 해방이후 긴급구호와 한국전쟁 직후 복구사업을 필두로 국제사회로부터 약 127 억불의 원조를 받아 경제 사회개발의 촉진제로 활 용하여 성장하였고, 2000년에 OECD DAC 수원국 리스트에서 제외되면서 수원국의 역사를 마무리 한다. 또한 1963년 USAID 자금을 통한 개도국 초청연수를 필두로 원조를 시작하여 87년 $\mathrm{EDCF}$ 와 
91년 KOICA 탄생으로 대외원조의 틀을 갖추었고, 2000년대부터는 원조규모를 급격히 증가시켜 09년까지 약 70 억불 규모의 원조를 국제사회에 기여하는 성과를 거두었다.

우리나라는 원조를 받아본 경험이 있는 나라이다. 또한 아직까지 국제사회에 준 것보다 받은 것이 많다. 원조를 받던 나라가 선진 공여국 클럽인 $\mathrm{OECD} \mathrm{DAC}$ 의 정식 회원국이 된 최초 국가이기도 하 다. 우리나라의 자립적인 성장모델은 많은 개도국의 벤치마킹 대상이 되고 있다. 이런 상황을 감 안할 때 우리나라의 원조는 단기적인 이해관계와 연계하지 않고 진정성을 갖고 겸손하게 수원국을 지원하는 방향으로 나가야 한다.

그러나 국내실태를 보면 이러한 원조방향을 추진할 수 있는 역량이 결집되지 못하고 있다. 유상과 무상이 분리되어 있고 무상도 30 여개 기관으로 분산 추진되고 있어 사업의 중복과 분절화 현상이 나 타나고 있다. 또한 유상과 무상별로 정책방향은 있으나 국가차원의 정책방향이 없는 실정이었다.

이러한 가운데 지난해 국제개발협력기본법이 의원입법으로 제정되어 분산된 원조체계를 통합적으 로 운영할 수 있는 기본 틀이 마련되었고 이를 토대로 금년초 국무총리실에 신설된 개발협력정책관 실을 중심으로 그동안 학계, 연구소, $\mathrm{NGO}$ 등 각계의 의견수렴을 거쳐 관계부처 합동으로 우리나 라 국제개발협력의 정책방안 수립작업을 진행하였다. 그 결실이 지난 10 월 25 일 국무총리 주재 국 제개발협력위원회에서 심의 확정된 '국제개발협력 선진화 방안'이다.

이번에 발표된 국제개발협력 선진화 방안은 원조는 철저히 수원국 중심으로 겸손하게 추진한다는 전제하에 i) 우리나라 원조를 국제수준으로 업그레이드하고 ii) 분절화된 원조시스템을 효과적으 로 개편하며 iii) 우리나라의 특성을 원조와 연계시키고자 하는 노력이 담겨 있다. 무엇보다 중요 한 것은 범정부적으로 합의된 정책문서를 제시했다는 점이다. 앞으로 선진화 방안 중 미진한 부분 은 지속적으로 검토 보완해 나갈 계획이다.

본고에서는 선진화방안의 핵심내용인 국제사회의 논의동향, 우리나라 개발협력의 현주소, 개발협 력의 추진방향, 개발협력의 3 대 선진화 전략, 개발협력의 기반확대를 중심으로 논의하고자 한다.

\section{II. 국제사회의 논의 동향}

그동안 개발협력은 시대적 상황에 따라 중점 목표를 달리하여 왔다. 40 년대는 마샬플랜을 통한 유 럽재건, 50 년대는 자유주의 수호를 위한 안보적 차원(동서문제), 60 년대는 경제성장과 근대화를 
통한 빈곤과 불평등 해소(남북문제), 70 년대는 인간의 기본욕구 충족, 80 년대는 신자유주의에 따 른 선진국 모델 구축, 90 년대는 원조피로 현상과 함께 지속가능발전이 강조되어 왔다. 2000년대 들어서는 $\mathrm{UN}$ 의 새천년개발목표(MDGs)가 개발협력의 가장 중요한 목표로 등장하면서 국제사회는 사회개발을 통한 빈곤퇴치에 역량을 집중하게 되었다.

이러한 가운데 2008년 글로벌 금융위기에 따른 세계적인 경기침체로 인해 선진공여국들은 원조규 모를 확대하기 어려워진 반면 개도국들은 개발수요가 급증하게 되는 상황에 직면하게 된다. $\mathrm{OECD}$ 는 공여국의 원조공약이 후퇴하지 않도록 하는 약속을 재확인(09.5월)하고 세계은행 등 MDB도 개 도국의 개발수요에 적극 대응키로 하는 등 국제적으로 발 빠른 대응이 이어졌지만 원조여건이 좋 아지기는 어려운 상황이 지속되고 있다.

개발협력의 역사적 흐름을 고찰해보면 원조의 중점이 자립성장의 기반 구축인지 시급한 빈곤퇴치 를 통한 최소한의 인간다운 삶을 구현하는 것인지에 대한 논의가 계속되는 것을 볼 수 있다. 전자 는 역량배양(Capacity Building)이 전제되기 때문에 비교적 시간이 오래 걸리고 우리나라를 비롯 한 소수의 국가만이 성공했으며 성장의 과실이 빈곤층까지 전달될 수 있느냐에 의문을 제기한다. 후자는 원조의 효과가 직접적으로 나타나지만 원조가 중단되면 다시 빈곤상태로 전략할 우려가 있 기 때문에 지속적인 원조가 필요하다는 점을 지적한다.

필자의 개인적인 견해로는 두 가지 모두 포기할 수 없는 개발협력의 중요한 목표이다. 단기적으로는 시급한 빈곤퇴치에 기여하면서 동시에 중장기적으로 자립성장을 하도록 도움을 주어야 한다. 또한 두 가지 목표는 추진과정에서 상호 보완될 수 있는 영역도 많다. 빈곤퇴치를 통해 열심히 일할 수 있는 여건을 만들어 줄 수 있고 자립성장 지원과정에서 개도국에 일자리를 창출하여 빈곤을 퇴치할 수 있다. 여기서 중요한 것은 어떤 분야에 지원하던지 원조의 성공사례를 창출해야 한다는 것이다. 즉 원조의 효과가 명확하게 드러날 수 있도록 지원하는 것이 필요하다. 성공사례가 대내외에 알려지 게 되고 이를 배우려는 사람들이 많아지면 그 사례는 자발적으로 확산될 수 있다는 점에 주목할 필 요가 있다. 원조는 사업 그 자체의 성공도 중요하지만 지속적인 인센티브를 통해 그 사례가 확대 재생산될 수 있는 선순환 구조를 만들어 낼 수 있다면 더할 나위 없이 좋은 원조라고 생각한다.

세계화 시대에 국가간 관계는 넓고 깊어졌기 때문에 특정국가의 문제는 지구촌 문제가 되고 어느 국가이던지 독립적으로 생존하기 어려운 구조로 변모하고 있다. 그렇기 때문에 국제사회의 공동대응 은 그 어느 때보다 중요해 지고 있고 개발협력도 이를 달성하기 위한 글로벌 공공재에 대한 투자로 인식되고 있으며 개도국의 실질적 발전을 지원하는 통합적 협력에 초점을 둔 개발(Development) 이슈로 범위를 확대해 나가고 있다. 
최근 UN, OECD 등 국제사회에서는 원조규모의 확대(More Aid), 원조 효과성 제고(Better Aid), 글로벌 원조체제(Aid Architecture)의 변화에 큰 관심을 가지고 있다. 즉 원조규모를 늘리고 공여 국과 수원국의 파트너십으로 원조의 효과성을 높이며 다양한 원조주체들간 분절화 방지를 위해 조 화와 협력을 추구하자는 것이 핵심요지이다.

원조규모 확대(More Aid)를 위해 GNI 대비 원조규모를 국가별로 확대하는 문제, 항공권 연대 기 여금 등 새로운 혁신재원을 마련하는 문제, 민간과 함께 원조를 추진하는 PPP 활성화 등이 활발 히 논의되고 있다. 원조 효과성 제고문제(Better Aid)는 현재 OECD DAC을 중심으로 논의가 진 행 중인데 03 년에는 수원국 시스템과 공여국의 정책·절차·관행 조화를 위한 원조조화에 관한 로 마선언(HLF-1)이 발표되었고, 05 년에는 수원국의 주인의식, 성과중심 등을 담은 원조효과성에 관 한 파리선언(HLF-2)이 채택되었으며, 08년에는 원조효과성에 관한 파리선언을 보완하기 위한 구 체적 이행방안이 아크라(HLF-3)에서 논의 되었다. 특히 아크라에서는 전통적인 공여자외에 글로 벌 펀드, 시민사회, $\mathrm{NGO}$ 와의 파트너십이 강조되었다. 글로벌 원조체제의 변화(Aid Architecture)와 관련해서는 06 년 기준으로 467 개의 양자 및 다자원조기관이 존재하고, 중국, 인도 등 새로운 공 여자의 증가로 인해 $\mathrm{DAC}$ 의 집단적 규제능력이 감소하고 있는 상황에서 공여국간 어떻게 효율적인 파트너십을 구축할 것인가가 수원국의 효과적 원조에 매우 중요한 요소로 등장하고 있는 것이다.

\section{III. 우리나라 개발협력의 현주소(2000년대)}

우리나라 원조의 가장 큰 특징은 추진체계가 다원화되어 있다는 것이다. 양자원조 중 유상은 재정 부가, 무상은 외교부와 30 여개 기관이 담당하고 있으며 다자원조 중 국제금융기구는 재정부가 UN 등 기타기구는 외교부와 일반부처가 담당하고 있다. 이러한 분산된 추진체계에서는 원조사업의 중 복과 분절화는 피할 수 없는 현상이다. 총리실에서 금년도 $\mathrm{ODA}$ 사업을 전수조사한 결과를 보면 약 1 조 3,500 억원의 재원을 가지고 32 개 기관이 160 여개 국가와 국제기구에 1,070 여개 사업을 추 진하는 것으로 나타났다. 사업내용에서도 새마을 운동 등 일부 분야에서 기관간 중복사업도 있는 것으로 나타났다.

$\mathrm{ODA}$ 담당기관 및 관련법 현황

\begin{tabular}{|c|c|c|c|}
\hline \multicolumn{2}{|c|}{ ODA 형태 } & 담당 기관 & 비 고 \\
\hline \multirow{2}{*}{ 양자원조 } & 유상원조 & 기획재정부(EDCF) & 대외경제협력기금법 \\
\cline { 2 - 4 } & 무상원조 & 외교부(KOICA), 30개 기관 & 한국국제협력단법 등 \\
\hline \multirow{2}{*}{ 다자원조 } & 국제금융기구 & 기획재정부 & 국제금융기구가입조치법 \\
\cline { 2 - 4 } & 기타 국제기구 & 외교부 및 개별기관 & \\
\hline
\end{tabular}


그나마 다행인 것은 2000 년 이후 원조규모가 크게 증가했다는 것이다. 2000년 2.1억불에서 2009 년 8.2억불로 약 4 배 증가 하였는 바, 절대적 원조규모는 적지만 증가속도는 매우 주목할 만하다. 원조구성(00 08년)을 지역별로 보면 아시아가 약 $68 \%$, 아프리카 약 $12 \%$, 중남미 약 $8 \%$ 순이며, 사업형태별로는 프로젝트의 비중이 압도적으로 높다.

2000년대 ODA 규모 변화 추이

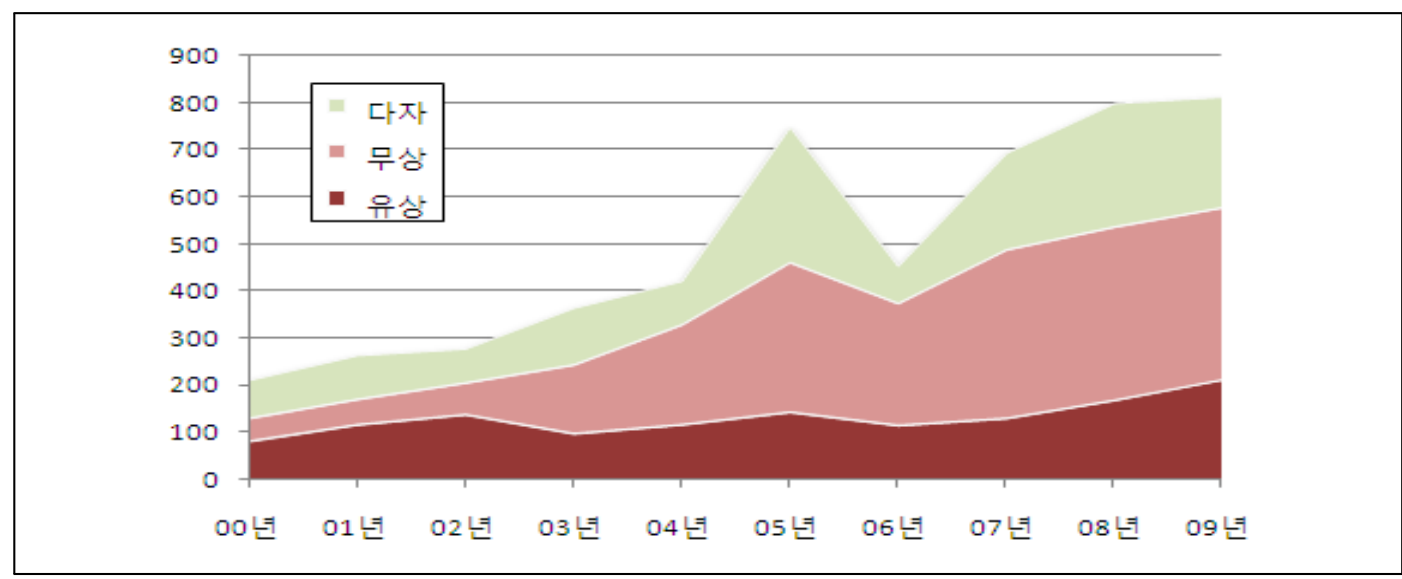

$\mathrm{OECD} \mathrm{DAC} \mathrm{회원국과} \mathrm{비교분석해} \mathrm{보면} \mathrm{우리나라는} \mathrm{아직} \mathrm{국제기준에} \mathrm{미흡하다는} \mathrm{것을} \mathrm{알} \mathrm{수} \mathrm{있다.}$ 우리나라의 2009년 원조규모는 8.15억불이고 GNI 대비 비율은 $0.1 \%$ 인데 규모면에서는 DAC 23 개 회원국 중 19 위이고 GNI 대비 비율면에서는 최하위이다. 또한 2008년 유상비율은 우리나라가 총 지출 기준 $36.3 \%$ 로서 $\mathrm{DAC}$ 회원국 평균 $12.6 \%$ 에 비해 높은 편이며 $\mathrm{DAC}$ 회원국 중에는 일본, 포 르투갈에 이어 3 위이다. $\mathrm{DAC}$ 회원국 중 유상을 실시하는 나라는 총 8 개국이며 유무상 기관이 분 리된 국가는 프랑스(시행기관은 통합), 이태리, 한국 등 3 개국이다. 2008년 비구속성 비율은 우리 나라가 $35.8 \%$ 로서 $\mathrm{DAC}$ 회원국의 $86.5 \%$ 에 비해 매우 낮은 편이다.

우리나라의 개발협력은 그동안 짧은 역사에 비해 적지 않은 성과를 거두었으나 아직까지 여러 측 면에서 미흡하다. 첫째, 국가차원의 컨트롤 타워기능이 취약하고 국가차원의 유기적인 전략이 없 었다는 점, 둘째, DAC 회원국과 비교할 때 우리나라는 원조규모나 유무상 비율, 비구속성 비율 등 주요 지표가 국제기준에 미흡하다는 점, 셋째, $\mathrm{ODA}$ 에 대한 국민적 공감대가 미흡하고 전문인 력 등 추진 인프라가 취약하며, $\mathrm{NGO}$, 기업 등민간과의 연계를 통한 입체적인 접근이 부족했다는 점이다. 


\section{IV. 국제개발협력 추진방향}

\section{1. 우리나라의 국제개발협력 환경}

우리나라의 국제개발협력 추진방향을 설정하기 위해서는 우리를 둘러싼 환경을 살펴보아야 한다. 우리나라는 세계에서 유일하게 최빈국에서 선진공여국 클립인 DAC에 가입한 최초의 국가이다. 그 렇기 때문에 우리는 선진국과 차별화되면서 개도국에 도움을 줄 수 있는 특유의 잠재력을 가지고 있다. 농업중심에서 산업화-정보화 단계를 거쳐 단기간에 빈곤을 탈출한 다양한 분야의 경험을 가 지고 있을 뿐 아니라 개도국과 유사한 식민지 독립과 전쟁경험이 있어 심리적인 동질감과 신뢰감 형성이 용이하다. 그렇기 때문에 개도국은 우리 발전모델에 대해 진정으로 관심이 많으며 국제사 회에서는 선진국과 개도국간 가교역할을 할 수 있는 좋은 위치에 있다는 것이다.

하지만 이러한 우리의 강점이 곧바로 $\mathrm{ODA}$ 성공적 추진으로 이어지는 것은 아니다. 이를 $\mathrm{ODA}$ 에 잘 활용하기 위해서는 우선 겸손해야 하며 진정성을 담아야 한다. 우리가 한수 가르쳐 준다는 식 의 접근은 위험하다.

또한 우리나라는 짧은 역사로 추진체계가 분산되어 있고 $\mathrm{ODA}$ 에 대한 국민적 공감대가 미흡하며 인력양성 등 추진 인프라가 취약하기 때문에 국제기준에 맞는 원조의 선진화를 위해서는 압축적인 개발전략이 필요한 시점이다. 국제사회의 주요 의제인 원조규모 확대, 원조 효과성 제고, 글로벌 원 조체제의 변화 등에 적극적으로 대응할 수 있도록 국내 역량을 결집하는 것이 필요하다.

이러한 인식을 토대로 수립한 선진화 방안의 전체내용은 다음의 표와 같다.

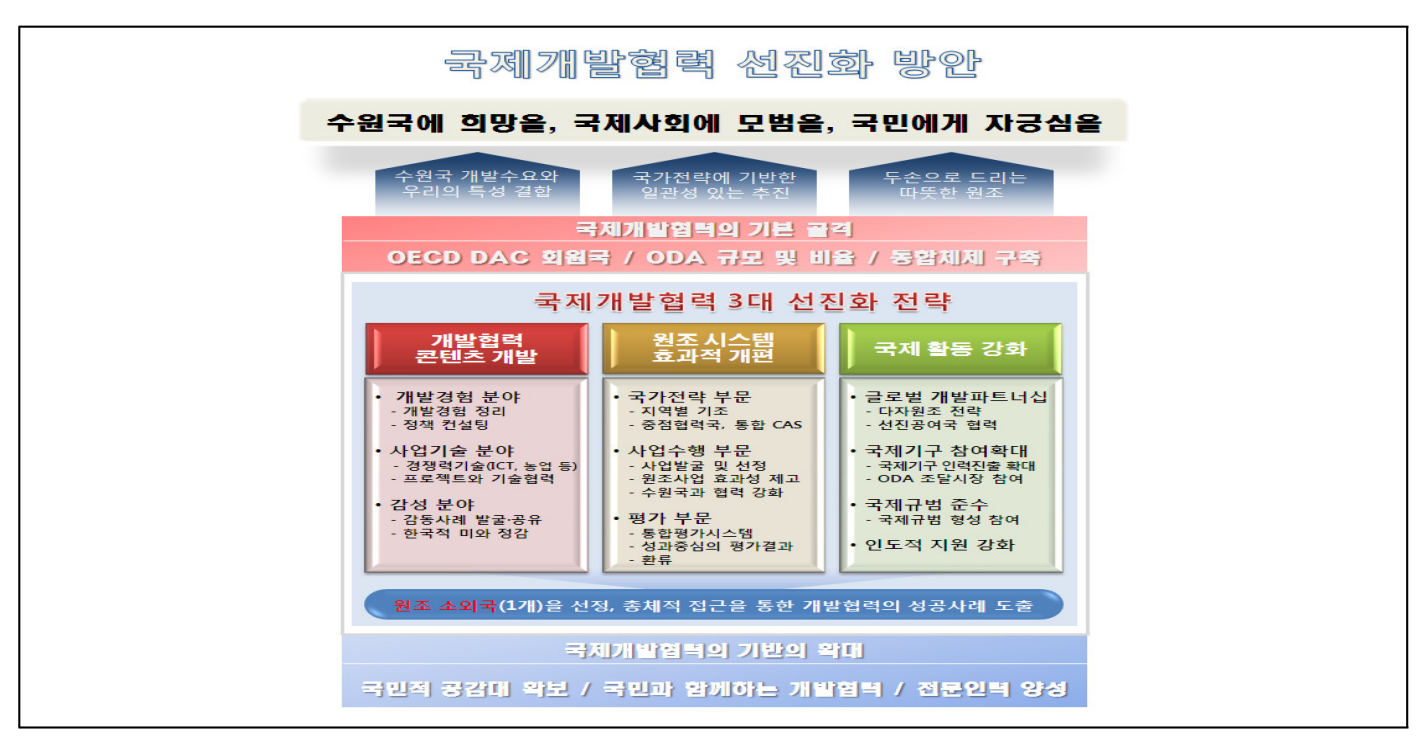




\section{2. 국제개발협력의 이념과 추진방식}

우리나라 국제개발협력의 기본정신은 국제개발협력기본법 제 3 조에 명시되어있다.

개도국의 빈곤감소, 여성 및 아동의 인권향상과 성평등 실현, 지속가능한 발전 및 인도주의 실현, 협 력대상국과의 경제협력관계 증진, 국제사회의 평화와 번영 등이다. 선진화 방안에서는 이러한 기 본정신을 충실히 이행하는 과정에서 염두해 두어야 할 3 대 가치를 설정하였다.

첫째 '수원국에 희망을' 주어야 한다. 자립성장에 성공한 우리나라는 개도국에 희망을 줄 수 있는 위치에 있다. 우리나라의 발전경험을 토대로 역량배양(Capacity Building)을 통한 자립능력 개발 에 초점을 두면서 시급한 빈곤퇴치에도 기여를 해야 한다. 둘째, '국제사회에 모범을' 보여야 한다. 인도주의, 인권, 기후변화 대응 등 글로벌 이슈에 적극 동참하면서 $\mathrm{UN}, \mathrm{OECD}$ 등 국제기구 활동 에도 적극 참여하여 국제사회의 보편적 가치를 추구해야 한다. 셋째, '국민에게 자긍심을' 주어야 한다. 국민의 세금으로 개도국을 지원하는 것이기 때문에 국민들의 자부심과 세계시민의식을 함양 하는 계기가 되어 국격을 향상하는 데 기여해야 한다.

국제개발협력의 기본정신과 3 대 가치를 구체적으로 실현하기 위해서는 이에 맞는 추진방식이 필요 하다. 먼저 수원국의 개발수요와 우리의 특성을 결합한 원조를 해야 한다. 수원국이 원하는 사업 중 발전경험을 살려 우리가 잘하는 분야에 원조가 이루어져야 한다. 이를 위해서는 국내 ODA 자 원과 역량을 결집할 수 있는 시스템을 구축해야 하는 데, 양자와 다자, 유상과 무상, $\mathrm{H} / \mathrm{w}$ 와 $\mathrm{S} / \mathrm{W}$ 원조가 유기적으로 연계되고 부처간 협력시스템을 구축하여 시너지를 극대화 할 수 있는 통합적 접근 방식으로 원조체계가 개편되어야 한다. 마지막으로는 진정성을 담아 두 손으로 드리는 따뜻 한 원조가 되어야 한다. 도움을 받았던 때를 떠올려 수원국의 마음을 얻어야 한다. 원조를 단기적 인 이해관계와 연계시키는 것은 바람직하지 않다.

\section{3. 국제개발협력의 기본골격}

우리나라 국제개발협력의 큰 틀을 구성하는 요소는 크게 i) OECD DAC회원국으로서의 역할, ii) 우리나라 ODA의 규모와 비율, iii) 국제개발협력기본법상의 유무상 통합추진체계이다.

먼저 우리나라는 $\mathrm{OECD} \mathrm{DAC}$ 회원국으로서 국제사회가 정한 원칙과 규범을 준수하고 글로벌 스탠 다드에 맞는 개발협력을 추진해야 한다. 이를 위해 $\mathrm{DAC}$ 의 새로운 규범형성과정에 적극 참여하는 한 편 2008년도 $\mathrm{DAC}$ 의 특별권고사항(5개분야, 17 개항목)을 착실히 이행해야 한다. 5 개분야인 추진체 
계, 규모 및 배분, 시행조직, 원조효과성, 인도적 지원에 관한 권고사항은 대부분 이번 선진화 방 안에 담겨있다.

이번에 우리나라는 2015년까지 ODA 규모를 GNI 대비 $0.25 \%$ 까지 확대하겠다는 약속을 재확인 하 였다. 이는 2009년 대비 ODA 규모가 약 3 배 증가하는 규모이며, 2000년 대비로 보면 약 12 배가 넘 는 규모이다. 절대적 규모는 많지 않지만 우리나라처럼 ODA가 빠르게 증가하는 나라는 드물 것으 로 보인다. 양자와 다자의 비율도 70:30 수준으로 유지하는 가이드라인을 설정했다. 이는 $\mathrm{OECD}$ $\mathrm{DAC}$ 회원국 평균과 비슷한 수준이다. 유무상 비율은 순지출 기준으로 $40: 60$ 내외로 유지하기로 하였다. 또한 비구속성 비율은 2015년까지 $75 \%$ 수준으로 끌어올리기로 하였다. 이는 무상은 $100 \%$, 유상은 $50 \%$ 까지 비율을 높이는 것으로서 국제기준에는 미흡하지만, 비구속성 비율 증가속도는 매 우 빠른 것으로 볼 수 있다.

연차별 ODA 확대계획

\begin{tabular}{|c|c|c|c|c|c|c|c|}
\hline 연도별 & '09 실적 & '10 예상 & 2011 & 2012 & 2013 & 2014 & 2015 \\
\hline ODA/GNI(\%) & 0.10 & 0.11 & 0.13 & 0.15 & 0.18 & 0.21 & 0.25 \\
\hline
\end{tabular}

또한 국제개발협력기본법령의 취지에 맞게 앞서 지적한 우리나라 ODA의 분산된 추진체계를 개편 하기 위해 국제개발협력위원회(위원장 : 국무총리) 중심으로 유무상 통합추진체계를 구축하였다. 유 무상 분야별로 주관기관과 협의체를 두고, 국가별로 현지에도 협의체를 두어 기관간 조율기능을 강화하는 한편 국제개발협력위원회에서 유무상 기본계획, 시행계획은 물론 유무상 중점협력국, 유 무상 통합평가, 유무상 통합홍보 등을 다룰 수 있도록 하였다.

\section{V. 국제개발협력 3 대 선진화 전략}

국제개발협력의 기본골격 하에 3대 선진화 전략을 수립하였는데, 그 취지는 우리나라만의 독특한 특 성을 $\mathrm{ODA}$ 와 연계시키면서 국내 분산된 역량을 결집할 수 있도록 시스템을 효과적으로 개편하고 국제사회의 논의동향에 적극적으로 참여하자는 것으로 요약할 수 있다. 하나하나 살펴보기로 한다.

\section{1. 개발협력 콘텐츠 개발}

우리나라는 최빈국에서 단기간내 경제성장과 민주화를 이룬 국가로서 선진국과 차별화되는 특유의 $\mathrm{ODA}$ 잠재력이 있다. 발전의지가 강한 개도국이나 다양한 국제기구에서도 이러한 한국적 모델에 
큰 관심을 표명하고 있다. 이러한 잠재력을 $\mathrm{ODA}$ 와 어떻게 연계시킬 것인가는 매우 중요한 문제이 다. 다시 한번 강조하지만 수원국이 아닌 우리 중심으로 이 과제를 접근해서는 안된다. 그동안 여 러 기관에서 이러한 아이디어에 착안하여 ODA 사업을 추진하여 왔다. 재정부는 04년부터 KSP라 는 정책자문사업을 통하여 지금까지 약 200 여개의 컨설팅을 하였다. 외교부는 KOICA를 통해 우 리나라의 발전경험을 바탕으로 행정, 교육 등 다양한 분야에 정책컨설팅과 기술컨설팅을 해오고 있으며 현재 그간의 사업경험을 토대로 ODA 모델을 추진 중에 있다. 농식품부는 새마을 운동에 기반을 둔 농촌개발과 농업기술 등을 중심으로 프로젝트와 기술전수 등을 추진 중이며, 복지부는 국제보건의료재단을 중심으로 우리의 개발경험을 정리하여 한국형 보건의료 원조모델을 수립 중에 있고, 교과부도 한국형 교육발전 모델을 구축할 예정이다.

이런 방식으로 개발경험 정리와 정책자문사업을 추진할 경우 대상국가와 자문사업이 기관간 중복 될 우려가 있고, 통일된 가이드라인이 없어 정리방법이나 체계면에서 혼란스러울 수 있다. 또한 정책자문결과가 후속 $\mathrm{ODA}$ 사업으로 연계되기 위해서는 자문의 정교함과 함께, 관계기관간 유기적 인 협조가 절실하다. 또한 우리의 강점은 과거의 개발경험에만 있는 것이 아니라 현재 보유한 기 술에도 있다. 프로젝트나 기술협력에 당장 활용해도 개도국에 파급효과가 큰 것도 많이 있다. 예 를 들면 미주개발은행(IDA)의 신탁기금을 활용하여 대한지적공사가 우리나라 제도에 기반하여 자 메이카 토지등기 프로젝트에 컨설팅을 수행하였고 이를 계기로 500 만불 규모의 본 사업이 진행되 게 되었다. 또한 농촌진흥청에서 케냐에 우리의 못자리 기술과 탈곡기를 전수하여 쌀 생산량을 약 $20 \%$ 증가시킨 사례도 있다. 이렇듯 우리가 가진 제도와 기술을 활용하면 한국적 특성을 살리면서 개도국에 큰 도움이 되는 $\mathrm{ODA}$ 의 사업영역은 무궁무진하다.

이러한 인식에 기반을 두고 개발협력콘텐츠 개발 방안을 마련하였다. 아직 개발의 초기단계인 만큼 개발협력 콘텐츠를 체계적으로 분류하여 점진적으로 추진하되, 개발과정에서 부처의 참여를 강화 하는 방향으로 추진토록 하였다.

개발협력 콘텐츠 개발 분야 및 소관부처

\begin{tabular}{|c|c|c|}
\hline 8대 분야 & 소관부처(참여기관) & 비 고 \\
\hline 경제 & 재정부 & \multirow{8}{*}{$\begin{array}{l}\text { - Cross-cutting Issue } \\
\text { : 여성부 등 } \\
\text { - 감성분야 } \\
\text { : 문화부 }\end{array}$} \\
\hline 보건의료 & 복지부(식약청) & \\
\hline 인적자원 & 교과부, 고용부 & \\
\hline 행정·ICT & 행안부, 법무부, 방통위, 지경부 & \\
\hline 농어업 & 농식품부(농진청), 행안부 & \\
\hline 국토건설 & 국토부 & \\
\hline 환경 & 환경부 & \\
\hline 산업에너지 & 지경부(중기청) & \\
\hline
\end{tabular}


먼저 그동안의 원조경험과 원조수요를 감안하여 콘텐츠는 8대 분야를 선정하여 중점적으로 개발키 로 하였다. 8대 분야는 경제, 보건의료, 인적자원, 행정·ICT, 농어업, 국토건설, 환경, 산업에너 지로 하고, 저탄소 녹색성장, 여성 및 인권 등은 범분야(Cross-cutting Issue)에 포함시켰다. 물 론 분야별 소관부처를 지정하였다.

한편, 콘텐츠는 3 개로 나누어 구축키로 하였는데, 첫째, 과거 우리가 경험했던 우수한 정책과 제 도로서 개도국의 발전에 도움이 되는 개발경험 분야이다. 이는 주로 정책컨설팅에 활용될 수 있으 며, 예를 들면 경제개발계획, 토지등기제도, 수출 진흥정책 등이다. 재정부를 중심으로 추진키로 하 였다.

둘째, 현재 우리가 보유한 사업 기술로서 개도국에 효과가 큰 사업을 발굴하는 것이며, 이는 프로 젝트나 기술협력에 활용될 수 있다. 예를 들면 농산물 재배기술, 전자정부 시스템, 전력망 구축기 술 등이며, 외교부를 중심으로 추진키로 하였다. 사업기술은 전 부처청(산하기관 포함)을 대상으로 발굴 정리하기로 하였고 $\mathrm{KOICA}$ 나 $\mathrm{EDCF}$ 도 그동안의 원조사업경험을 토대로 자체적으로 정리키로 하였다. 이를 통해 경쟁력 있는 원조사업을 발굴하여 KOICA나 EDCF 사업영역의 외연을 넓히는 데 크게 도움이 될 것으로 생각된다.

마지막으로 감성분야인데 특유의 한국적 감성 또는 美를 가미하거나 진정성을 느낄 수 있는 감동 사례를 발굴하자는 것으로서 우리나라 ODA의 부가가치를 높이는 데 기여할 것으로 보며 문화부 와 $\mathrm{KOICA}, \mathrm{EDCF}$ 를 중심으로 추진키로 하였다.

개발경험, 사업기술, 감성분야를 유기적으로 조합하고 국내기관간 협조체계, 원조사업의 입체적 구성, 수원국 중심의 원조방식, 사업의 사후관리 등을 종합하면 한국의 특성이 담긴 원조모델이 된다. 원조모델은 원조사업을 체계적이고 유기적으로 추진하기 위한 필수요소로서 원조사업의 분 절화를 막고 사업간 시너지 효과를 발휘하는 데 가장 좋은 수단이다. 당연히 원조모델은 개도국의 상황에 따라 변형, 수정되어 지원해야 한다. 우선 시범적으로 새마을 운동, 직업훈련프로그램, 모 자보건 사업 등 3 개 사업을 대상으로 구축하고 점차 확대해 나갈 계획이다.

또한 우리나라의 발전모델 자체에 관심이 갖는 개도국의 최고위급 인사가 많기 때문에 이들에게 일목요연하게 설명할 수 있도록 1 시간 정도 분량의 총체적 개발경험 콘텐츠를 개발하기로 하였다. 이 자료는 개도국의 수요에 맞게 영어, 불어, 서반아어로 번역하고 개도국 입장에서 관심 있는 한 국의 핵심적인 발전과정을 담아 성공요인과 문제점 등을 입체적으로 정리할 계획이다. 


\section{2. 원조시스템의 효과적 개편}

원조시스템은 국가전략부문, 사업수행체계부문, 평가부문으로 크게 나눌 수 있다. 먼저 어느 규모 로 어떤 지역에 어떤 목적을 가지고 어떤 사업을 지원해야 하는지에 대한 국가전략을 수립하고 이 에 따라 실제 사업을 집행한 후 그 원조가 어떤 효과가 있었는지에 대한 평가가 이루어진다. 이런 시스템은 $\mathrm{ODA}$ 분야에만 적용되는 것이 아니라 모든 분야에 적용되는 일반원칙이라 하겠다.

지금까지 보면 유상(재정부)과 무상(외교부 등 30 여개 기관)이 각각의 원조시스템에 따라 운영되 었기 때문에 부처차원의 합리성을 담보하고 있을 뿐 국가차원의 합리성을 충족시키기는 미흡했다. 따라서 이번 선진화 방안에서는 이러한 원조시스템을 효과적으로 개편키로 한 것이다.

원조시스템의 첫 번째 단계는 유무상 통합전략 수립이다. 여기에는 지역별 정책기조, 유무상 통합 중점협력국가, 유무상 통합 국가지원전략이라는 3 가지 핵심요소가 있다.

지역별 정책기조는 $\mathrm{ODA}$ 전략과 재원배분의 기본 틀을 설정함으로써 원조의 예측가능성을 높이고 체계적인 원조를 시행하기 위해 필수적이다. 그동안의 지역별 지원실적과 우리나라의 국정방향 등 을 고려하여 다음과 같이 정했다. 아시아는 그동안의 긴밀한 협력관계를 바탕으로 최우선 중점기 조를 그대로 유지키로 하였고 양자원조의 $55 \%$ 내외를 지원하되 빈곤정도와 발전단계 등을 종합적 으로 고려하여 지원할 계획이다. 아프리카는 빈곤감축을 위한 인도적 지원을 강화하면서 자립과 성장기반 확충을 중심으로 협력을 확대하고 양자원조의 $20 \%$ 내외를 지원할 계획이다. 중남미는 우 리의 개발경험과 발전모델에 대한 관심증가 등 개발협력 수요에 대응하여 지원을 확대하고 양자원 조의 $10 \%$ 내외를 지원할 계획이다. 중동.CIS는 이라크 등 취약국가에 대한 지원강화와 함께 중점협 력국을 중심으로 국가별 특성에 맞게 지원을 추진하되, 양자원조의 $10 \%$ 내외를 지원할 계획이다. 오세아니아와 기타 지역은 원조에 소외된 지역을 중심으로 양자원조의 $5 \%$ 내외를 지원할 계획이다.

유무상 통합중점협력국가는 한정된 재원을 선택과 집중에 따라 효과적으로 활용하기 위해 필요하 다. 지금까지 유상과 무상이 각각 운영해 것을 통합하여 중점협력국가를 26 개국을 축소하는 한편 이 국가들에 대한 지원을 유무상 각각 $70 \%$ 이상으로 설정하였다. 유무상 통합 중점협력국은 $\mathrm{OECD}$ $\mathrm{DAC}$ 수원국 리스트에 있는 152 개국중 소득수준이 가장 높은 그룹의 국가들은 모두 제외하고 중 하위소득이하 국가 109 개국을 대상으로 국제적인 원조기준, 원조수행 여건 등을 고려하고 지역안 배, 소득수준 등을 종합적으로 검토하여 선정하였다. 중점협력국은 3년 단위로 재검토할 예정이고 불가피한 경우에는 3 년 이전이라도 국제개발협력위원회의 심의를 거쳐 변경할 수 있도록 하였다. 
중점협력국에 선정된 국가에 대해서는 국가지원전략(CAS)을 수립할 계획인데, 지금까지 유상과 무상이 각각 수립해 온 것을 통합적으로 수립토록 하였다. 2012년까지 수원국의 개발계획 수립시 점과 연계하여 CAS를 수립하되 금년에 베트남 등 3 개국에 대해 우선 착수할 예정이다. 유무상 통 합 국가지원전략을 수립하기 위해서는 재정부, 외교부, $\mathrm{KOICA}, \mathrm{EDCF}$ 등 유관기관 합동으로 작업 을 해야 한다. 따라서 좋은 수립절차의 선례를 남겨야 하기 때문에 총리실 중심으로 베트남 CAS 를 시범적으로 마련할 계획이다. 또한 내실있는 CAS 수립을 위해서는 폭넓은 의견수렴이 필수적 인 만큼 $\mathrm{CAS}$ 초안을 공개하여 다양한 목소리를 들을 예정이며 CAS가 실질적인 ODA의 지원 기본 지침으로 활용될 수 있도록 역량을 결집할 계획이다. 이를 위해 총리실에서는 이미 통합 CAS 가 이드라인을 작성 관계기관에 배포하였다.

원조시스템의 두 번째 단계는 사업수행체제의 선진화이다. 여기에는 사업발굴 및 선정절차, 원조 사업의 효과성 제고, 수원국과 협력 강화라는 3 가지 핵심요소가 있다.

사업발굴과 선정절차는 재정부와 외교부가 주로 주관해 왔고 관계부처의 협의절차가 있으나 사실 상 내실 있게 진행되지 못한 측면이 있었다. 특히 우리나라 ODA 규모가 2009년 대비 2015년까지 약 3 배정도 증가할 것이기 때문에 풍부한 사업발굴은 필수적이며 사업선정과정에서 전문성을 보유 한 부처의 협의과정도 중요해 질 수밖에 없다. 앞으로 사업발굴에서는 $\mathrm{NGO,} \mathrm{연구소,} \mathrm{민간기업} \mathrm{등}$ 다양한 의견수렴절차와 함께 현장을 중요시 할 계획이다. 내년에 $\mathrm{KOICA}$ 와 $\mathrm{EDCF}$ 의 인력이 증가 할 계획인데 이러한 필요성과 무관치 않다. 독일의 경우 독일하우스라는 한 건물에 다양한 원조기 관이 모여 현지정보를 공유하고 협력을 강화하고 있는 점을 고려하여 우리도 가급적 현지에서 원 조관련기관을 한 곳에 모을 예정이다. 또한 개발협력 콘텐츠 개발과정에서 각 부처청이 제시하는 사업기술 분야도 적극적으로 반영할 계획이다. 사업발굴을 위한 수원국과의 정책협의도 국내 유무상 기관이 협의하여 일관성 있게 추진할 방침이다. 사업선정과정에서는 사업이 사실상 확정되기 이전 에 관계부처의 충분한 사업을 검토해야 하기 때문에 유상과 무상별로 협의시점을 앞당길 방침이다.

원조사업의 효과성 제고는 매우 중요한 분야이다. 국가의 $\mathrm{ODA}$ 전략을 비롯한 모든 노력의 결과가 원조사업으로 나타나기 때문이다. 아무리 원조가 국제기준에 맞고 전략이 좋아도 실제 원조사업이 효과가 없다면 성공했다고 볼 수 없다. 앞서 금년도 우리나라 ODA 전수조사 결과에서 보듯이 지 금처럼 30 여개 기관이 개별적으로 1,070 여개 사업을 분절적으로 추진한다면 결코 바람직한 원조 라 할 수 없을 것이다. 다양한 분야나 지역에 다양한 사업을 하는 것보다는 핵심 분야나 지역에 사업을 집중시켜 지속적으로 관리하는 것이 효과가 크다는 것은 당연한 일이다. 따라서 효과성 제 고를 위해서 중요한 것은 원조 사업을 상호 연계 추진하는 것과 원조사업을 효율적으로 개편을 하 는 것이다. 
원조사업의 연계는 크게 유상사업과 무상사업의 연계, 정부와 민간사업의 연계, 패키지형 사업 추 진으로 나눌 수 있다. 유상사업과 무상사업의 연계 취지는 유상과 무상의 지원영역이 비교적 구분 되어 있다는 점에서 출발한다. 유상은 대규모 자금이 투입되는 인프라 사업에 주로 활용되며 무상 은 비교적 소규모 자금이면서 다양한 분야에 활용된다. 그렇기 때문에 유상과 무상을 연계하면 시 너지를 창출할 가능성이 많다. 예를 들어 무상으로 개발조사나 $\mathrm{KSP}$ 를 하고 그 결과를 바탕으로 유상 프로젝트 사업을 하는 방안이 있고, 대규모 병원을 유상으로 건립하면 그 운영을 무상자금으 로 하는 방안도 고려할 수 있으며 하나의 마을을 선정하여 유상자금으로 전력을 공급해 주고 무상 으로 학교나 보건소를 지어주는 방안도 생각할 수 있다. 91년 09년중 유상과 무상의 연계사업은 총 22 건이나 유무상 연계를 전제로 양기관이 협의하여 추진한 사례는 1 건도 없다. 그동안 유무상 이 연계된 경우는 수원국의 요청에 따라 먼저 개발조사사업을 시행한 이후 이를 토대로 수원국이 우리나라에 유상사업을 요청하여 이루어 진 것이다. 이는 엄격한 의미의 유무상 연계라고 보기는 어렵다. 따라서 내년부터는 적절한 사업을 선정하여 유무상 연계를 시범적으로 추진할 계획이다.

\section{유무상 연계사업 모형(예시)}

- (모형 1) 개발조사/KSP(무상) + 프로젝트 사업(유상)

- 무상으로 신도시 마스터플랜을 수립, 유상으로 핵심시설인 교량을 건립

- 지금까지 우리나라 유·무상 연계 모형

- (모형 2) 프로젝트 사업(유상) + 프로젝트 운영(무상)

- 유상으로 병원건축, 무상으로 연수생초청, 전문가 파견, 봉사단을 활용하여 기술지원

- (모형 3) 동일한 지역내 연계 : 인프라(유상) + 사회교육시설(무상)

- 동일 지역에 유상으로 전력공급 후, 무상으로 학교를 건축

- (모형 4) 역량강화사업(무상) + 인프라(유상)

정부사업과 민간사업의 연계도 각자의 노하우가 다르다는 전제에서 출발하는데 예를 들면 정부에 서 아동교육시설을 건립하면 $\mathrm{NGO}$ 에서 이를 운영하는 방안, 정부와 기업이 함께 한 지역에 시너 지를 창출하는 사업을 연계하여 지원하는 방안 등을 고려해 볼 수 있다. 특히 PPP는 국제사회에 서도 강조하는 이슈인바, 글로벌 기업의 경우 사회적 책임(CSR)이 중요시 되고 있기 때문에 정부 와 기업이 함께 개도국 지원에 나선다면 다양한 원조사업의 연계가 가능하여 원조의 효과성이 크 게 높아질 뿐 아니라 국가와 기업 브랜드 향상에도 크게 도움이 될 것으로 보인다. 금년에 우리나 라도 KOICA에서 처음으로 PPP사업을 시행하였으나 그 규모도 작고 아직은 다양한 아이디어가 부족한 상황이다. 내년부터는 정부와 민간 사업의 연계를 구체적으로 설계하여 본격적으로 추진할 예정이다. 
패키지형 사업은 $\mathrm{ODA}$ 의 종합세트 개념으로서 중점분야나 중점지역을 선정하여 다양한 원조사업 을 유기적으로 연계하여 지원하는 방식이다. 하나의 공여국이 하나의 개도국의 당면한 모든 개발문 제를 한정된 ODA 자금으로 해결할 수 없다. 그렇다면 가장 좋은 방법은 하나의 분야나 지역을 선 정하여 종합적이고 지속적인 지원을 통하여 뚜렷한 개발효과를 거두는 성공사례를 만드는 것이다. 성공사례에 대한 벤치마킹을 하도록 유도하여 개도국에 인센티브를 주고 개발효과를 확산시키는 것 이다. 예를 들면 한 마을의 농가소득 증대를 위한 개발협력을 한다면 타당성 조사를 통해 그 마을에 필요한 모든 요소들을 추출하여 관개수로나 가공시설을 건립하고 초청연수나 전문가 파견을 통해 기 술 전수를 해 주며 농기계 등 기자재 지원과 함께 사후관리로서 시설과 기계의 유지보수와 판로개척 까지 자문을 해주는 것이다. 이와 함께 주민들이 자발적으로 배우고 일할 수 있도록 역량배양까지 책임지는 형태를 생각해 볼 수 있다. 즉 원조는 물적 요소와 지식이 함께 들어가며 인센티브까지 주 는 것이라면 더더욱 좋은 것이다. 이를 위해 개도국에 필요한 요소 중 선진국과 차별되는 우리의 개 발경험과 사업기술을 최대한 활용할 수 있도록 국내 전문기관간 협력체제를 구축하고 원조의 지속가 능성을 유지시켜 준다면 완벽에 가까운 원조모델을 창출할 수 있는 것이다. 기존의 원조를 시행했 던 지역으로 대상으로 패키지형 사업을 추진한다면 더욱 효율적일 것이다. 정부는 내년에 개도국의 중점분야나 중점지역을 선정하여 패키지형 사업을 구체화하여 본격적으로 추진해 나갈 방침이다.

이제 원조사업별로 효율성을 제고할 수 있는 방안을 논의해 보고자 한다. 먼저 개발조사사업 또는 개발경험 공유사업은 선진화 방안의 개발협력콘텐츠 개발과 관련되어 있고 후속 ODA 사업과 연 계가 가능한 점을 감안하여 사업비중을 확대할 계획이다.

프로젝트 사업은 사업선정시 지속가능성 여부를 중요시 할 계획이다. 이는 사업의 면밀한 검토가 필 요하다는 의미이다. 아무리 좋은 사업이라도 그 사업이 지속적으로 활용되지 않는다면 의미가 없다. 예를 들어 발전소를 건립해 주었는데 고장이 나도 고칠 수 있는 능력이 되지 않아 가동하지 않는다 면 곤란하다. 인터넷 등 $\mathrm{PC}$ 를 이용할 수 있는 센터를 건립해 주었는데 수원국의 인터넷 이용 요금 이 너무 비싸 사실상 운영되기 어렵다면 곤란하다. 직업훈련원을 건립해 주었는데 그 위치가 너무 외 진 곳에 있어 실제 훈련 받으러 가기 어렵다면 곤란하다. 따라서 사업결과의 지속가능성을 사업선정 시 고려하고 수원국에게 자립적으로 운영할 수 있게 하는 것은 $\mathrm{ODA}$ 의 본질적인 부분이라 하겠다.

초청연수는 현재 여러 기관에 분산되어 있어 중복이 많은 분야이기 때문에 외교부(KOICA)가 초청 연수 사업을 총괄 기획하여 중복을 없애는 한편 교육 콘텐츠와 교육운영은 각 기관의 전문성을 최 대한 활용할 계획이다. 아울러 개도국에서 귀중한 시간을 내서 우리나라에 방문한 교육생들에게 보다 효과적인 교육이 이루어 질 수 있도록 교육과정의 업그레이드 방안도 강구할 계획이다. 또한 초청연수와 프로젝트 사업 간의 연계도 강화할 계획이다. 
봉사단은 현재 부처별로 분산되어 있는 바, 중장기 자문단(외교부), IT 청년봉사단(행안부), 대학 생봉사단(교과부), 퇴직전문가(지경부)의 사업을 KOICA의 World Friends Korea로 사업예산을 통 합하기로 하였다. 봉사단 규모는 연차적으로 늘려나갈 계획이다.

원조가 수원국 중심으로 되어야 효과성이 높아진다는 것은 너무나 당연한 이야기다. 특히 우리나 라와 관련하여 수원국이 제기하는 사항을 중심으로 살펴본다면, 우선, 우리나라가 개별부처별로 수원국을 직접 접촉하다 보니 혼란스럽다는 문제제기가 있었다. 이에 따라, 가급적 협의 창구를 단일화하기 위하여 재외공관과의 역할을 강화할 계획이다. 또한 우리나라는 1 년 단위로 수원국에 지원계획을 협의하기 때문에 수원국이 $\mathrm{ODA}$ 지원을 토대로 중장기 개발계획을 수립하기 어렵고 원조의 예측가능성도 떨어진다는 지적이 있어 시범적으로 3 년 단위의 지원계획을 마련할 계획이 다. 또한 원조는 수원국에게 인센티브를 줌으로써 $\mathrm{ODA}$ 지원사업을 꾸준히 이끌어 나갈 수 있도록 자립기반을 만들어 주는 것이 매우 중요하다. 이를 위해 사업종료 5-10년후 자립여건 조성여부를 판단하여 사후관리 종료여부를 결정하는 방안 도입을 추진할 계획이다.

원조시스템의 세 번째 단계는 평가이다. 평가는 바람직한 $\mathrm{ODA}$ 를 위한 핵심요소이다. 지금까지는 유상과 무상이 각각 자체평가를 실시하여 객관성 부족과 관대화 경향이 발생하고 평가의 사각지대 가 생기는 문제가 있었다. 또한 프로젝트 평가위주로 평가가 진행되어 주제별, 국별, 유무상 연계 평가 등 다양한 평가가 미흡하였고 평가결과의 피드백 조치도 미흡하였다. 따라서 총리실을 중심 으로 지난해에는 유무상 ODA 통합평가 지침을 마련하고 국제개발협력위원회 산하 평가소위원회 (위원장 : 국정운영1실장)를 중심으로 평가를 담당키로 하였다.

\section{통합평가 흐름}

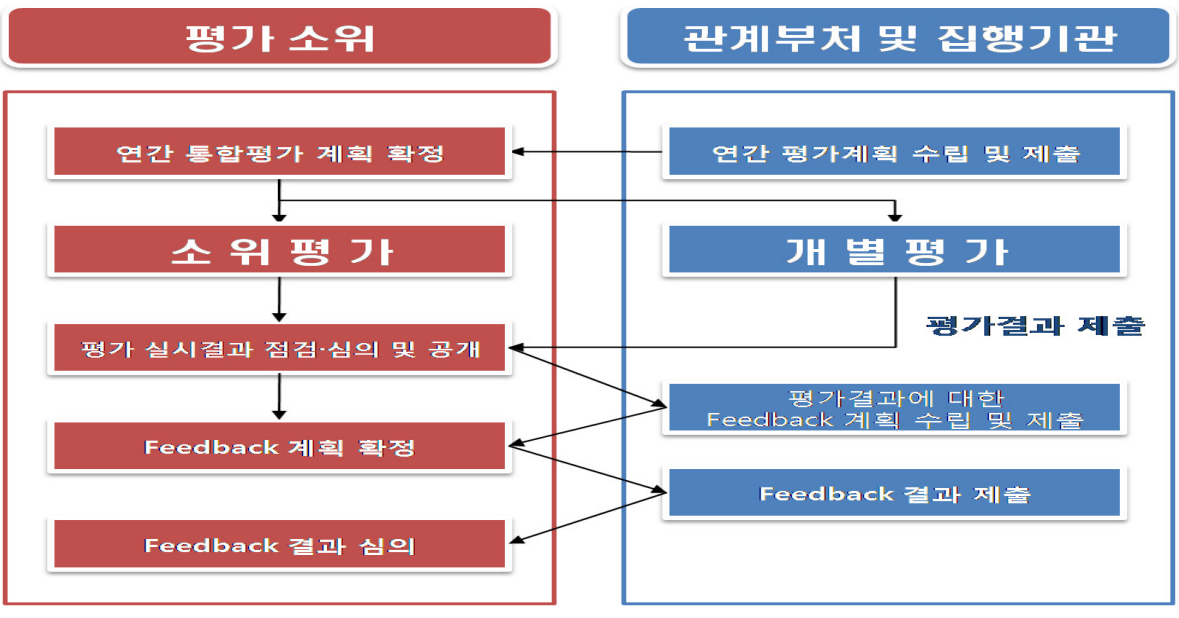


평가소위가 주요 주제에 대해 직접 평가를 하고, 시행기관별 자체평가 결과는 평가소위에서 심의 하도록 하였다. 금년에는 평가소위에서 새마을 운동 전수사업, 캄보디아 국별평가, 유무상 연계사 업 등 3 개 사업을 민관합동으로 평가하고 있다. 앞으로 평가과정에서는 수원국의 의견 수렴을 강 화하고 평가결과를 공개할 계획이다.

\section{3. 국제활동 강화}

$\mathrm{OECD} \mathrm{DAC}$ 회원국이자 G20 의장국으로서 이제 우리나라는 국제사회의 당면한 문제 해결에 적극 참여할 때이다. 특히 선진국과 개도국의 가교역할을 할 수 있는 우리나라는 국제사회에서 독특한 역할을 담당할 수 있고 이를 위한 체계적인 방안이 필요하다.

이를 위해서 글로벌 개발파트너십 강화, 국제기구에의 우리 국민과 기업의 참여확대, 국제규범 준 수 및 형성과정의 참여, 해외긴급구호 등 인도적 지원확대가 필요하다.

글로벌 개발파트너십 강화를 위해서는 우선 다자원조에 대한 통합적 전략이 필요하다. 지금까지 다자원조도 부처별로 추진되고 이를 조율하는 기능이 거의 없었던 점을 감안하여 금번에 몇 가지 기본 방침을 정하였다. 다자개발은행 $(\mathrm{MDB})$ 에 대한 지원을 지속하면서 $\mathrm{UN}$ 등 기타 국제기구에 대 한 지원도 단계적으로 확대함으로써, MDGs 달성, 기후변화, 식량안보 등 글로벌 이슈 해결에 적극 참여하는 한편, 양자차원의 접근이 어려운 취약국가나 인도지원 분야를 중점 지원하기로 하였다. 또한 집행상황을 모니터링 할 수 있는 신탁기금을 적극 활용하여 국제기구의 노하우와 전문성을 적극 활용키로 하였으며 이 과정에서 $\mathrm{UN} \cdot \mathrm{MDB}$ 간 기능분담 및 공동사업에 대한 관계부처간 협의를 강화해나가기로 하였다. 또한, 원조과정에서 선진공여국과 국제기구와의 협력을 강화해 나가기로 하 였다. 우리의 지원대상국 중 선진공여국의 원조가 많은 국가에 대해서는 원조분업을 적극 실시하되, 우리의 비교우위 분야와 지역에서의 공동협력 사업을 강화하는 한편 유망프로젝트 등에 있어 국제 기구와의 협력사업을 강화하고 우리의 발전경험을 활용한 공동사업 및 컨설팅을 추진키로 하였다.

국제기구에 우리인력과 기업의 진출을 확대하기로 하였다. 엄밀히 보면 ODA라 볼 수는 없지만 부 처별로 분산 추진되고 있는 점을 감안하여 이번에 추진 틀을 마련키로 한 것이다. 우리국민들의 국제기구 진출에 관심은 증가하고 있으나 우리 국제적 위상이 비해 진출규모는 미흡한 실정이다. 우리나라의 $\mathrm{UN}$ 에 대한 분담율은 2010년 2.26\%로서 11위이지만 전문직(P급)이상 진출규모는 37 위 에 불과하다. 국제금융기구도 사정은 비슷하다. 우리나라의 평균지분은 $1.48 \%$ 인데 비해 진출비율 은 $0.7 \%$ 에 불과하다. 이러한 상황을 개선해 나가기 위해 총리실에 국제기구 진출확대 실무 $\mathrm{T} / \mathrm{F}$ 를 설치하고 재정부, 외교부, 각 부처별 담당자를 지정하였다. 국제기구에 진출할 수 있는 다양한 루 
트를 개발하는 것이 중요한데 우선 국제기구 초급전문가(JPO) 파견을 대폭 확대하는 한편 ODA 규모 확대에 따라 국제기구의 자발적 기여금과 신탁기금 지원을 확대하고 이에 부합하도록 우리 국민의 진출을 확대할 예정이다. 또한 현재의 의무분담금/출자금 대비 과소진출문제는 국제기구 사무국과 교섭 강화를 통해 개선해 나갈 방침이다.

이와 아울러 국제기구 진출을 위한 저변도 확대하기로 하였다. 글로벌 청년리더 10 만명 양성계획 에 따라 국제기구 인턴 파견을 확대하고 UNV 등 국제기구와 연계하여 현장경험 기회를 확대하면 서 $\mathrm{UN}$ 의 여성인력 우대정책 등을 감안하여 여성인력진출을 적극 지원하기로 하였다. 국제기구 진 출설명회 정례화, 초중고 및 대학의 글로벌 진로교육 강화 등도 지속적으로 추진하기로 하였다.

국제사회의 $\mathrm{ODA}$ 규모 증가와 비구속성 원조 확대 등으로 $\mathrm{ODA}$ 조달시장 규모가 확대되고 있으나 우리기업의 진출은 저조한 상황이다. 연간 규모로 볼 때, 국제기구 조달시장은 약 400 억 달러, 양 자 $\mathrm{ODA}$ 조달시장 중 경쟁가능한 시장이 약 670 억 달러정도로 큰 시장이다. 특히 국제기구 조달 시장은 비교적 투명하고 공정한 경쟁이 가능하기 때문에 우리기업의 진출가능성이 높은 블루오션의 영역이라 할 수 있다. 그러나 ODA 조달시장은 발주기관이 위험 최소화를 위해 조달실적 업체를 선호하는 등 초기진입장벽이 높고, 진출을 준비하는데 시간이 오래 걸리며 발주기관별로 절차도 달 라 잠재적 유망기업도 섣불리 진출을 결정하지 못하는 경우가 많다. 정부 내에서도 이를 담당하는 기관이 지경부, 재정부, 외교부, 국토부, 중기청, 조달청 등 분산되어 있어 체계적인 지원이 이루 어지지 못하는 실정이다. 우리나라도 $\mathrm{ODA}$ 의 비구속성 비율이 높아지기 때문에 우리기업도 이제는 국제 $\mathrm{ODA}$ 조달시장에 관심을 갖고 적극적으로 대응할 때라고 생각된다. 따라서 정부에서는 정부 내 분산된 추진체계를 유기적으로 연계시키고, 기업들의 국제 ODA 조달시장에 관심을 갖게 하기 위한 설명회, 진출에 필요한 정보, 매뉴얼 등을 제공하는 등 다양한 대책을 마련할 계획이다.

국제원조규범을 준수하고 규범형성과정에 참여하는 것은 매우 중요하다. 특히 UN의 MDGs는 물 론 몬테레이 UN 개발재원 고위급 회의(02년)에서 논의된 ODA 규모의 지속적 확대 원칙, 그리고 $\mathrm{DAC}$ 의 원조공여조건에 관한 권고(78년), 최빈국에 대한 비구속화 권고(01년)는 물론, 정책일관성, 역량배양, 성평등, 빈곤감소, 취약국 지원, 거버넌스 등 $\mathrm{DAC}$ 의 가이드라인을 준수해 나갈 계획이 다. 또한 $\mathrm{HLF}$ 의 파리선언(05년), 아크라 행동계획(08년)의 이행에도 만전을 기할 계획이다. 이를 위해 매년 우리 $\mathrm{ODA}$ 의 국제규범 준수 실적을 매년 평가하여 이행상황을 점검할 계획이다.

내년에는 부산에서 HLF-4가 개최된다. 이를 준비하기 위해 외교부에 기획단을 설치하고 국제개 발협력위원회를 중심으로 현안을 조율해 나갈 계획이다. 이 과정에서 우리나라는 규범형성과정에 적극 참여해 나간다는 방침이다. 
마지막으로 해외긴급구호에 대하여 살펴보도록 하겠다. 세계적으로 인도적 지원수요는 지속적으로 증가하는 추세를 보이고 있다. UN에 의하면 1975 2005년간 국제사회의 자연재해 발생건수는 연평 균 100 건에서 400 건으로 증가하였기 때문에 긴급구호분야에 보다 더 큰 관심이 필요하다. 금년 초 에는 아이티 지진피해를 계기로 우리정부의 긴급구호 선진화 필요성이 대두되어 다양한 대책을 수 립하였다. 먼저 금년 긴급구호예산은 95 억원으로 우리 ODA 규모대비 $0.87 \%$ 수준에 불과하여 지 진, 수해 등 해외재난 발생시 효과적인 지원이 어려웠다. 따라서 긴급구호 예산비중을 2015년까지 $\mathrm{DAC}$ 회원국 평균수준인 $6 \%$ 로 확대하기로 하였다. 또한 대규모 재난 상황발생시 24시간 내에 외 교부 주관으로 관계부처 회의를 개최하여 긴급구호대 파견여부와 초기지원규모를 결정하고, 긴급 구호에 전문화된 인력 양성과 이동식 병원, 통신장비 등 긴급구호 장비의 비축 확대, 민간구호기 관, NGO 등의 현장 활동지원 강화를 추진해 나가기로 하였다.

\section{VI. 국제개발협력의 기반 확대}

우리나라 ODA가 성공적으로 추진되기 위해서는 인프라가 잘 구축되어야 한다. 특히 ODA에 대한 국민적 공감대가 있어야 하고, 정부와 민간부문이 함께 ODA를 추진할 수 있는 여건이 마련되어야 하며 $\mathrm{ODA}$ 전문 인력의 저변이 넓어야 한다. 이러한 분야는 중장기적으로 지속적인 노력이 필요한 분야로서 범정부적인 역량결집이 무엇보다 중요하다.

$\mathrm{ODA}$ 는 국민의 세금으로 지원되는 것이기 때문에 무엇보다 국민적 공감대 확보가 매우 중요하다. 특히 $\mathrm{ODA}$ 를 통해서 국격이 높아지고 자긍심을 가질 수 있다는 점과 ODA 규모가 확대되는 것에 대한 국민적 이해도를 높이는 것이 급선무이다. 이를 위해 유상과 무상으로 분리된 홍보추진체계 를 통합하고 대한민국 통합 ODA 홈페이지와 $\mathrm{BI}(B r a n d$ Identity)를 도입할 계획이다. 또한 금년도 에는 초중고 교과서 내용을 수정하여 ODA 기본취지를 담았으며, 주요 대학의 ODA 관련과정, 단 기캠프, 특강 등 개설과 세미나 개최 등을 적극 지원하고 있으며 일반국민들도 ODA 필요성을 체 감할 수 있도록 홍보관, 박람회 등을 체험기회를 확대할 계획이다.

정부와 민간부문이 함께하는 개발협력을 구현하기 위해 먼저 $\mathrm{NGO}$ 와 협력을 강화해 나갈 계획이 다. $\mathrm{NGO}$ 를 실질적인 개발협력의 파트너로 인정하는 한편 협력사업비를 15 년까지 10 배 확대하기 로 하였으며 정부 보조금 비중도 12 년까지 $80 \%$ 로 연차별로 확대하기로 하였다. 또한 사업발굴에 서 평가에 이르는 일련의 과정에서 $\mathrm{NGO}$ 의 전문성을 활용하기 위해 참여를 확대할 계획이다. 
기업과의 협력도 중요하다. 기업이 개발협력의 주체이자 후원자로서 활동할 수 있도록 PPP 예산 의 확대와 함께, 기업의 사회적 책임(CSR)과 연계하여 정부와 협력할 수 있는 모델을 구축할 계획 이다.

대학과 연구기관과의 협력도 강화할 계획이다. $\mathrm{ODA}$ 정책개발과 사업발굴의 전문기관으로서 싱크 탱크로 활용하는 방안을 강구하고 있다. 대학과 연구소별로 전문분야, 대상국가 등을 지정하여 연 구협력 체제를 구축하고 연구조사 업무에 대한 업무위탁을 확대하며 대학, 연구소, NGO, 정부기 관의 인적, 물적 교류 활성화, 이론과 실제가 결합된 연구성과 도출을 유도할 계획이다.

$\mathrm{ODA}$ 전문인력 역시 원조의 효과성을 높이기 위해서는 지속적으로 양성해 나가야 한다. 현재 대학 이나 대학원에서 $\mathrm{ODA}$ 에 대한 교과과정이 많아지고 있고 $\mathrm{ODA}$ 에 관심이 많은 퇴직 전문가도 늘어 나고 있다. 정부의 $\mathrm{ODA}$ 규모도 크게 증가할 것이기 때문에 인력수요와 공급규모가 동시에 커지고 있어 이에 대한 체계적인 관리가 시급하다. 특히 고부가가치 분야로 여겨지는 개발컨설팅 산업은 유망한 분야임에도 아직 미흡한 점이 많다. 이에 따라 정부는 전문인력을 국별전문가, 컨설턴트, 학생, 퇴직자로 나누어 ODA 사업과 연계하여 맞춤형 대책을 수립할 예정이다.

\section{VII. 결 론}

지금까지 국제개발협력 선진화 방안의 주요내용을 살펴보았다. 금년은 우리나라 국가 정책방향을 설정한 해라면 내년은 이를 효과적으로 추진해야 하는 해이다. 지금까지 각 부처가 해온 ODA 사 업 추진 관행이 있기 때문에 동 방안이 뿌리를 내리기에는 시간이 걸릴 수도 있다. 이와 더불어 선진화 방안도 앞으로 지속적으로 보완해 나가야 한다. 추진과정에서 좋은 아이디어는 반영하고 효과 없는 대책은 제외하는 작업을 부단히 해나가면서 우리나라 $\mathrm{ODA}$ 를 발전시켜 나갈 것이다. 앞 으로 우리나라 ODA 선진화를 위해 각계의 좋은 의견들을 기대하면서 이 글을 마치고자 한다. 


\section{참고 문헌}

국제개발협력위원회, 『국제개발협력 선진화 방안』(서울 : 국제개발협력위원회, 2010)

국제개발협력위원회, 『국제개발협력 통합평가 추진방안」(서울 : 국제개발협력위원회, 2010)

정우진, 『한국형 개발협력 모델』 KOICA 연구보고서(서울 : KOICA, 2010)

이경구, 『한국에 대한 개발원조와 협력』KOICA 연구보고서(서울: KOICA, 2004)

OECD(2008), Special Review of Korea, OECD DCD 